Provided for non-commercial research and education use. Not for reproduction, distribution or commercial use.

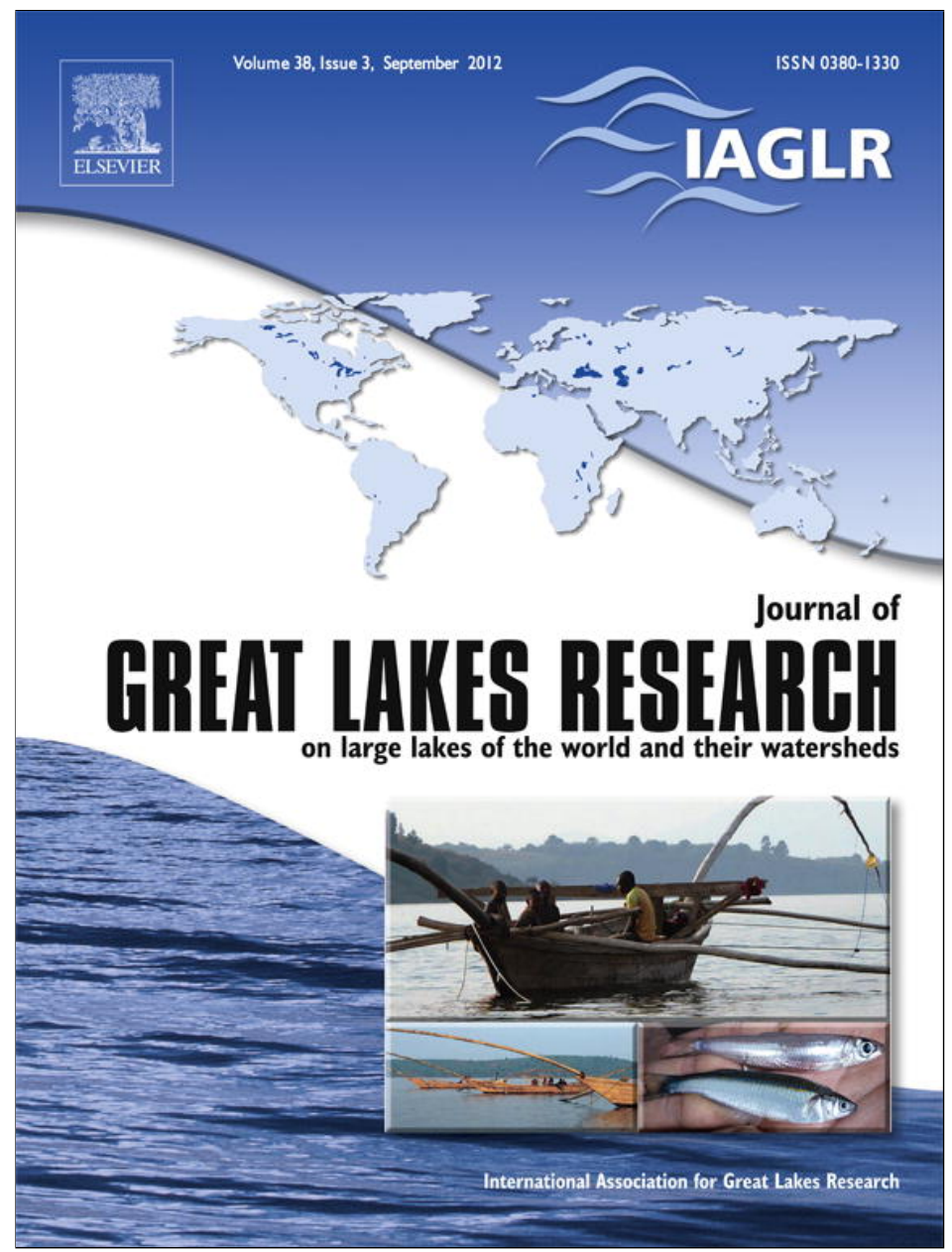

This article appeared in a journal published by Elsevier. The attached copy is furnished to the author for internal non-commercial research and education use, including for instruction at the authors institution and sharing with colleagues.

Other uses, including reproduction and distribution, or selling or licensing copies, or posting to personal, institutional or third party websites are prohibited.

In most cases authors are permitted to post their version of the article (e.g. in Word or Tex form) to their personal website or institutional repository. Authors requiring further information regarding Elsevier's archiving and manuscript policies are encouraged to visit:

http://www.elsevier.com/copyright 


\title{
Is the fishery of the introduced Tanganyika sardine (Limnothrissa miodon) in Lake Kivu (East Africa) sustainable?
}

\author{
Jean Guillard ${ }^{\mathrm{a}, *}$, François Darchambeau ${ }^{\mathrm{b}}$, Pascal Masilya Mulungula ${ }^{\mathrm{c}, \mathrm{d}}$, Jean-Pierre Descy ${ }^{\mathrm{d}}$ \\ a INRA, UMR CARRTEL, Centre Alpin de Recherche sur les Réseaux Trophiques et Ecosystèmes Limniques, 75, avenue de Corzent, F-74203 Thonon-les-Bains cedex, France \\ ${ }^{\mathrm{b}}$ Unité d'Océanographie Chimique, Département d'Astrophysique, Géophysique et Océanographie, Université de Liège, Allée du 6-Août 17, 4000 Liège, Belgique \\ c Unité d'Enseignement et de Recherche en Hydrobiologie Appliquée (UERHA) - Dpt. de Biologie - Chimie, I.S.P., Bukavu, Congo \\ d Laboratoire d'Ecologie des Eaux Douces, URBE, Département de Biologie, Université de Namur, Rue de Bruxelles 61, 5000 Namur, Belgique
}

\section{A R T I C L E I N F O}

\section{Article history:}

Received 16 November 2011

Accepted 9 May 2012

Available online 19 June 2012

Communicated by Lars Rudstam

\section{Keywords:}

Echo-integration

Hydroacoustic

Lake Kivu

Limnothrissa miodon

Pelagic fish

Stock assessment

\begin{abstract}
A B S T R A C T
Limnothrissa miodon, a small pelagic clupeid fish introduced at the end of the 1950s into Lake Kivu, became an important resource for the human populations of this area. The total stock of pelagic fish populations of this lake was estimated in 2008 by two hydroacoustic surveys, using an EK60 split-beam sounder (frequency $70 \mathrm{kHz}$ ). The total fish stocks were estimated to be approximately $5000 \mathrm{t}$ in the rainy season and 6000 tons in the dry season. These values are similar to previous estimations performed in the 1980s. During 2008 , the stock did not fluctuate throughout the seasons; however, the spatial distributions were different in the two hydrological seasons. Interestingly, the $L$. miodon stock has appeared to remain stable over the last two decades, which suggests that the pelagic fishery in Lake Kivu has not been overexploited and that it is sustainable.
\end{abstract}

() 2012 International Association for Great Lakes Research. Published by Elsevier B.V. All rights reserved.

\section{Introduction}

Introductions of species are widely regarded as detrimental (Gozlan, 2008; Leprieur et al., 2009; Vitule et al., 2009) and are considered as a major threat to biodiversity (Sala et al., 2000; Vitousek et al., 1997). Worldwide, but particularly in the African continent, introductions have been aimed to develop fisheries (Moreau et al., 1988). Often, the consequences have been reported as catastrophic for the native fauna, for the ecosystems, and for the well-being of the human populations, such as in the African Great Lakes (OgutuOhwayo et al., 1997). However, some cases have been reported as successful, as far as the fishery is concerned (Gozlan, 2008). For instance, the introduction of Tanganyika sardines, Limnothrissa miodon (Boulenger, 1906), in Lake Kivu (Spliethoff et al., 1983) seems to be productive even though the effects on the ecosystem and on the geochemistry of the whole lake are still matter of debate (Dumont, 1986; Isumbisho et al., 2006; Pasche et al., 2010).

Lake Kivu has a species-poor fish fauna compared to other large lakes of the East-African Rift valley (Beadle, 1981). While Lake Tanganyika and Lake Malawi harbour hundreds of endemic species,

\footnotetext{
* Corresponding author. Tel.: + 33450267851.

E-mail addresses: jean.guillard@thonon.inra.fr (J. Guillard), Francois.Darchambeau@ulg.ac.be (F. Darchambeau), pascalmasilya@yahoo.fr (P.M. Mulungula), jean-pierre.descy@fundp.ac.be (J.-P. Descy).
}

mostly Cichlidae, only 29 species have been described from Lake Kivu. Four of these species have been accidentally or deliberately introduced (Collart, 1960; Marshall, 1993; Snoeks et al., in press): three cichlids [Oreochromis macrochir (Boulenger, 1912), Oreochromis leucostictus (Trewavas, 1933) and Tilapia rendalli (Boulenger, 1897)], and one clupeid $L$. miodon (Boulenger, 1906). Recently, a fifth species, Lamprichthys tanganicanus (Boulenger, 1898), endemic to Lake Tanganyika (Coulter, 1991) has appeared in the commercial catches from several sites in Lake Kivu (Muderhwa and Matabaro, 2010), but with low occurrence in the pelagic area (Masilya, 2011). The species-poor fish fauna of Lake Kivu is due to profound geologic disturbances that occurred approximately 11,000 years BP (Haberyan and Hecky, 1987). Snoeks et al. (1997) gave a detailed account of the history and status of the ichtyofauna of Lake Kivu, providing evidence for the existence of 15 endemic haplochromines.

Among the introduced species, the most famous is the Tanganyika sardine, locally known as "Isambaza", L. miodon, which was deliberately introduced in 1959 (Collart, 1960) from Lake Tanganyika to occupy the pelagic area of Lake Kivu, which previously lacked pelagic fish species. $L$ miodon was introduced in an attempt to establish a pelagic fishery in Lake Kivu based on the pelagic planktonic food web. Despite the fact that this introduction might be considered as a disturbance of the pelagic ecosystem (Darchambeau et al., in press; Dumont, 1986; Isumbisho et al., 2004; Kaningini et al., 2003), it permitted the development of an important pelagic fishery with an 
annual exploitable stock that was estimated at approximately $7000 \mathrm{t}$ (FAO, 1992; Roest, 1999). However, rather pessimistic predictions on the sustainability of the L. miodon fishery were made by Dumont (1986), based on observed changes in the composition and biomass decline of mesozooplankton in the lake.

Major projects were enacted to manage the pelagic fishery of Lake Kivu, including the "Isambaza" project conducted by PNUD-FAO in Rwanda in the 1980s and the "Pêche du Sambaza au filet maillant dans le lac Kivu" conducted in Congo (Kaningini et al., 1999). Despite the systematic collection of data on total fishery yield by the Rwandan administration, the fishery pressure on different species is poorly known. Furthermore, no fishery independent survey has been conducted since the study of Lamboeuf (1991). Thus, a pelagic fishery management plan based on reliable data cannot proposed.Therefore, the only way to assess the sustainability of the pelagic fishery was to conduct a comprehensive stock assessment of the L. miodon with hydroacoustic methods, and compare our results with estimates reported by Lamboeuf (1991) 20 years earlier.

The use of hydroacoustic methods to estimate fish abundance in aquatic ecosystems is well accepted (Simmonds and MacLennan, 2005), particularly for the pelagic zones of lakes (Dunlop et al., 2010; Guillard et al., 2006; Johnson et al., 2004). By contrast, the use of gillnets for assessing fish stocks is likely to provide a biased picture of species composition and size-structure because of known issues with capturing small $(<10 \mathrm{~cm})$ fishes using this equipment (Kurkilahti et al., 2002; Prachalováa et al., 2009).

We conducted two hydroacoustic stock estimation surveys, during both rainy (February 2008) and dry (July 2008) seasons using a sampling design similar to that of Lamboeuf (1991), in order to determine whether or not the pelagic fish population has declined as predicted by Dumont (1986). In addition to the comparison with historical data, fish distributions across seasons were also studied.

\section{Material and methods}

Lake Kivu is a large (surface area $2370 \mathrm{~km}^{2}$ ), deep (maximum depth $489 \mathrm{~m}$ ), oligotrophic lake that belongs to the African Eastern Rift. The lake is meromictic, with oxygenated waters limited to the upper $60 \mathrm{~m}$ and permanently separated from deep waters by several steep salinity gradients (Degens et al., 1973). Given the location of Lake Kivu, just $2^{\circ}$ south of the Equator, but at relatively high elevation $(1463 \mathrm{~m})$, the average surface temperature ranges from 23 to $24^{\circ} \mathrm{C}$ and the temperature gradient is only 1 to $2{ }^{\circ} \mathrm{C}$ between the surface and the bottom of the mixolimnion. Therefore, surface cooling occurring in the dry season reduces the temperature gradient and promotes mixing of the first $60 \mathrm{~m}$, which increases the nutrient availability in the euphotic zone (ca. $18 \mathrm{~m}$ on average) and promotes phytoplankton development (Sarmento et al., 2006). The dry season mixing also oxygenates the water over the whole mixolimnion. Thus, mixing events extend the oxic layer, and provide the pelagic fish with access to increased planktonic resources, whereas the rainy season conditions reduce both the depth of the oxic layer and food resources for planktivores (Isumbisho et al., 2006; Sarmento et al., 2006).

The lake can be divided into four large basins (Fig. 1, Table 1) and two bays, the Bukavu Bay in the south and Kabuno Bay in the north. Kabuno Bay was not included in our surveys. The basins have different patterns of wind and precipitation resulting shift of several weeks of the dry season between the North and the South basins (Kwetuenda et al., 1989). The inshore area represents less than $10 \%$ of the area of Lake Kivu and was considered separately in our analyses. The two 2008 surveys were performed in two contrasted seasons: from February 15-22 (rainy season), and from July 05-11 (dry season), before the occurrence of the two seasonal peaks in fish reproduction (August to October and March to May, Kaningini et al., 1999). Surveys were performed during the daytime for both safety reasons and to be consistent with historical surveys (Lamboeuf, 1991). The routes (Fig. 1) covering $252 \mathrm{~km}$ in February and $345 \mathrm{~km}$ in July, were designed to cover all areas of the lake and have a cover ratio as defined by Aglen (1989) of approximately 6 (5.37 in February and 7.35 in July). Some transects were shortened due to periods of strong winds and for logistic reasons (mainly safe places to rest for the night). In the analyses, samples recorded in areas with bottom depths of $<50 \mathrm{~m}$ were considered as inshore areas. In addition, a night survey was repeated on a single daytime transect to highlight the variation between night and day. Temperature and oxygen vertical profiles (Fig. 1) were obtained using an YSI 6600 multiparameter probe.

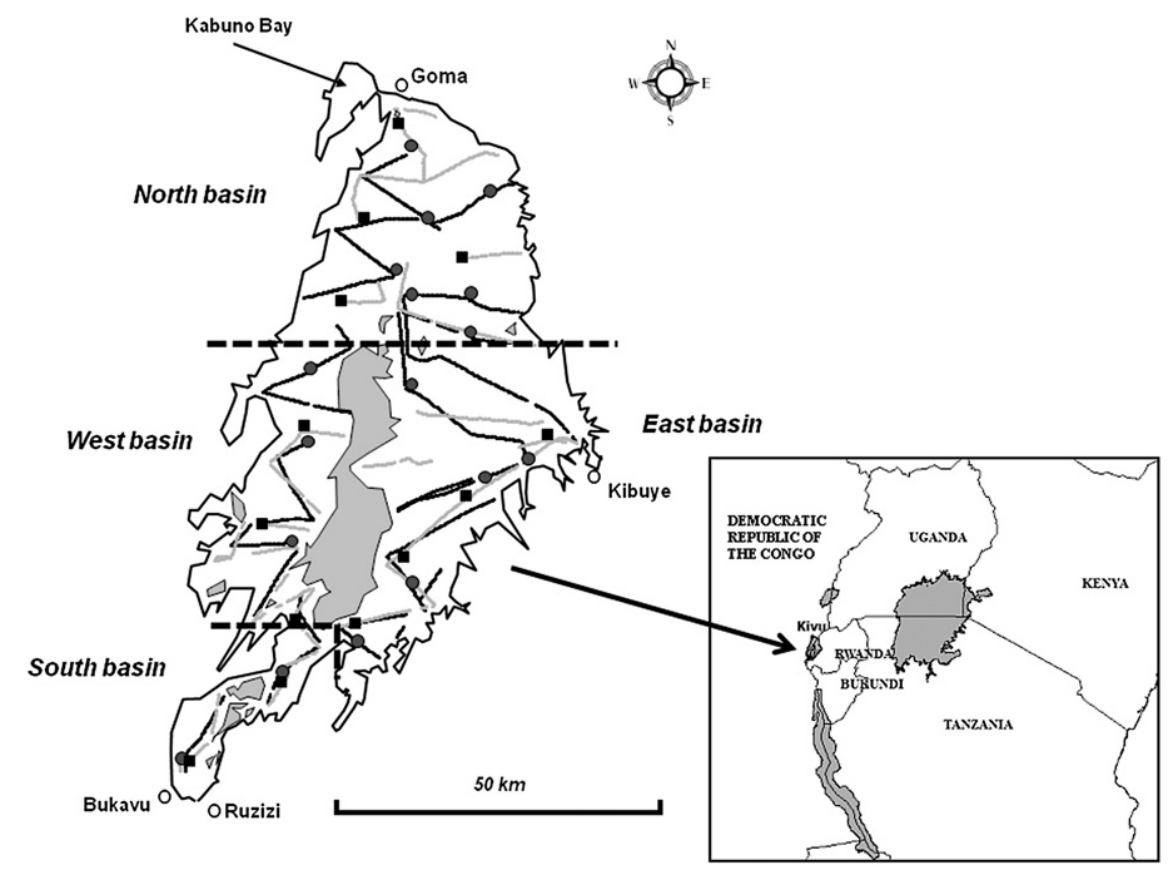

Fig. 1. Map of Lake Kivu showing the February 2008 (grey line) and July 2008 (black line) tracks and localization of the YSI profiles (February, black squares, July black circles). The dotted black lines showed the limit of the basins. 
Table 1

Morphometry of the pelagic area of the four main basins, and of the inshore area of Lake Kivu (from Kaningini et al., 1999).

\begin{tabular}{lcclcl}
\hline Basin & North & East & West & South & Inshore area \\
\hline Surface $\left(\mathrm{km}^{2}\right)$ & $900^{\mathrm{a}}$ & $900^{\mathrm{a}}$ & 320 & 97 & $50^{\mathrm{a}}$ \\
Depth max $(\mathrm{m})$ & 489 & 400 & 225 & 105 & 50 \\
\hline a Estimated. & & & & &
\end{tabular}

a Estimated.

The echosounder used was a Simrad EK60 equipped with a $70 \mathrm{kHz}$ split-beam transducer with a half-power beam angle of $11^{\circ}$. A GPS system was used to record boat positions. The collection parameters were a pulse-length of $0.256 \mathrm{~ms}$ (Godlewska et al., 2011) and 5 pulses per second. Sounder calibrations were performed annually in a large basin (IFREMER, Brest) according to the standard protocol of Foote et al. (1987), and the system was stable (gain variation $<0.4 \mathrm{~dB}$ ). The sound speed parameter and the attenuation coefficient $\alpha$ were adjusted for temperature based on collected profiles. Surveys were performed from a wooden boat, at a mean speed of $8 \mathrm{~km} \mathrm{~h}^{-1}$; the transducer was vertically attached to a pole along the boat at a depth of $0.5 \mathrm{~m}$. The acoustic data were analyzed using the Sonar5Pro software (Balk and Lindem, 2006) to calculate the total acoustic fish biomass in each depth layer and the acoustic size distributions. The processing thresholds were set at $-60 \mathrm{~dB}$ for single targets and $-55 \mathrm{~dB}$ for echointegration data, for consistency with those of Lamboeuf (1991). The Elementary Sampling Distance Unit (ESDU) was a priori fixed to $250 \mathrm{~m}$, according to previous analyses in other lake ecosystems (Guillard and Marchal, 2001). Previous studies on Lake Kivu (Lamboeuf, 1989) have demonstrated that fishes are not present at depths $>60 \mathrm{~m}$ due to the permanent lack of oxygen: therefore, data were recorded below this lower limit with in situ checking. Data were analyzed by vertical layers of $15 \mathrm{~m}$, like in the surveys carried out by Lamboeuf (1991): surface to $15 \mathrm{~m}, 15$ to $30 \mathrm{~m}, 30$ to $45 \mathrm{~m}$, and 45 to $60 \mathrm{~m}$. Fish area being proportional to acoustics backscattering (Simmonds and MacLennan, 2005), values were initially expressed in acoustic energy ( $s_{a}$ expressed $\mathrm{m}^{2} \mathrm{ha}^{-1}$ ) (MacLennan et al., 2002) reflected per layer and per unit of area, hereafter called acoustic biomass. Layered acoustic energy values were summed up by ESDU and the arithmetic mean acoustic biomass was computed for each basin. The arithmetic mean can be regarded as an unbiased estimate of the average in the area, if the effort is distributed in a homogeneous way, without initial statistical assumption (Smith, 1990). This estimator is similar to estimators obtained by other methods of calculation if the sampling effort is close to that recommended by Aglen (1989) (Guillard and Vergés, 2007). The whole lake acoustic biomass was given by the sum of each basin-specific mean acoustic biomass multiplied by the respective area of each basin. To estimate lake biomass, individual fish length and biomass were computed from single-echo observations. Single-echo detections criteria included echoes having 0.8-1.6 relative pulse widths, one-way beam compensation $<3 \mathrm{~dB}$, and a maximum phase deviation of 0.3 . To be classified as a tracked fish, traces had to include at least three echoes of the same target, separated by a maximum of one missing ping within a $0.3 \mathrm{~m}$ gating range (Balk and Lindem, 2006). From each tracked fish (see Fig. 4D), the average target strength (TS, dB) (MacLennan et al., 2002) was calculated in the linear domain. Frequency distribution of TS values was computed for each basin $i$. Each TS distribution was then split into 10 even-spaced frequency classes $c$ (i.e., decile classes). Due to the non normality of the distributions, median TS values by frequency class, $\mathrm{TS}_{c, i}$, were calculated for each basin and individual scattering cross-section $\left(\sigma, \mathrm{m}^{2}\right)$ was calculated following MacLennan et al. (2002):

$\sigma_{c, i}=10\left(\frac{T S_{c, i}}{10}\right) * 4 \pi$
Median individual fish lengths were calculated by basin for each TS frequency class using the TS-length relationship given by Lamboeuf (1991) for L. miodon in Lake Kivu:

$T S_{c, i}=20 \log _{10} L_{c, i}-67.6$

where $\mathrm{L}=$ total fish length $(\mathrm{cm})$. Median individual fish weights $(\mathrm{W}, \mathrm{g})$ were calculated by basin for each TS frequency class using the lengthweight relationship given by Lamboeuf (1989) for L. miodon in Lake Kivu:

$$
W_{c, i}=0.055 L_{c, i}^{2.27}
$$

The whole biomass per basin was calculated using the following equation:

$$
W_{i}=\sum_{c=1}^{10} \frac{p_{c, i} s a_{i}}{\sigma_{c, i}} W_{c, i}
$$

where $\mathrm{s}_{\mathrm{a} i}$ is the mean acoustic biomass of basin $i$ and $\mathrm{p}_{c, i}$ is the proportion of the acoustic biomass for the TS frequency class $c$ in basin $i$ and is given by:

$$
p_{c, i}=\frac{\sigma_{c, i}}{\sum_{c=1}^{10} \sigma_{c, i}}
$$

To generate confidence intervals for the fish biomass per basin and for the whole lake, we used a bootstrap approach that incorporated uncertainty in each of the following two estimates used to calculate the fish biomass: the mean $s_{a}$ per basin, the fish size structure. First, we randomly selected $s_{a}$ per basin with replacement and calculated a mean acoustic biomass, $s_{a i}$. Next, we randomly selected target strengths with replacement and calculated median TS values by frequency class, $\mathrm{TS}_{c, i}$. We then applied above-mentioned equations for calculating the whole biomass per basin, $\mathrm{W}_{i}$. This process was repeated 2500 times to generate a distribution of biomass estimates and calculate $95 \%$ confidence interval. The whole lake biomass was obtained by summing the four basin biomass plus the biomass observed in littoral areas.

The parametric one-way analysis of variance and post-hoc Tukey's HSD tests were used to compare acoustic biomass between basins and seasons. The heterogeneity of spatial distribution was given by the coefficient of variation ( $\mathrm{CV}=\mathrm{SD} / \mathrm{mean})$ of acoustic biomass. Multiple CV were compared using the Bennett's test as modified by Shafer and Sullivan (1986). The Kruskal-Wallis one-way analysis of variance was used to compare the estimated fish length distributions between seasons and areas. Bootstrap confidence intervals of biomass estimates were compared using Student's $t$ test.

\section{Results}

\section{Temperature and oxygen}

The water temperatures in the surface layer varied between 23.5 and $24.0^{\circ} \mathrm{C}$ regardless of the season (Fig. 2). In February, a thermocline around 30-40 m was recorded, while temperatures were almost constant in the mixolimnion during July (Fig. 2). During each survey, no difference in temperature and oxygen profiles was observed between basins: only the two profiles in the Bukavu Bay had a significantly lower surface temperature $\left(23.0^{\circ} \mathrm{C}\right)$. In February, the oxygen concentration rapidly decreased below $30 \mathrm{~m}$, with an oxycline ending at 35 to $50 \mathrm{~m}$ depending on the location (Fig. 3). In July, the oxycline was located at greater depths, ending between 50 and $60 \mathrm{~m}$. Waters below the oxycline were always anoxic. 
a

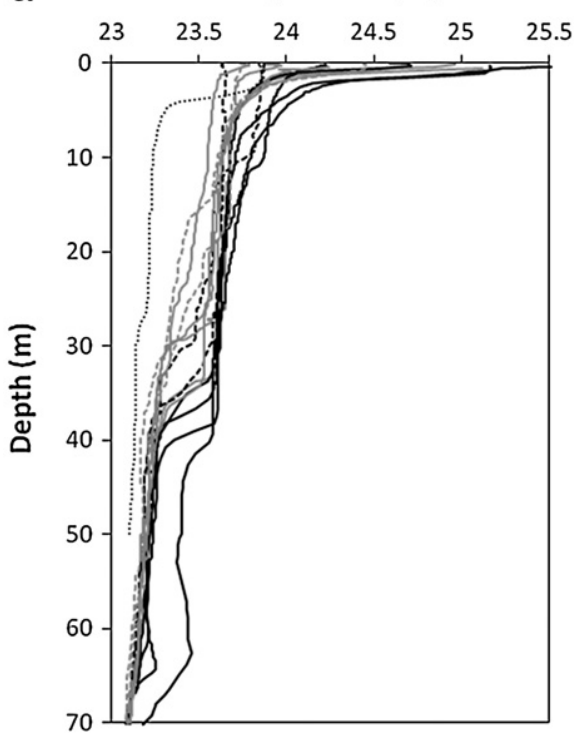

b

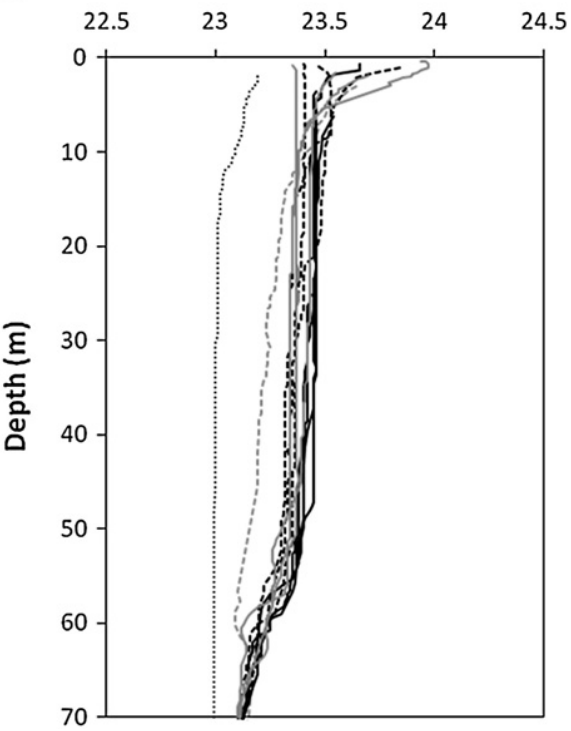

Fig. 2. Vertical temperature profiles in February (a) and July (b) 2008 in Lake Kivu. The continuous black lines represent the vertical profiles of the North basin, the continuous grey lines of the East basin, the dashed black lines of the West basin, the dashed grey lines of the South basin and the dotted black line of Bukavu Bay.

\section{Detected biomass}

\section{Echograms}

Observations performed during the daytime showed no target in layers close to the surface and in layers below $60 \mathrm{~m}$. Several kinds of structures were identified (Fig. 4) including individual fish, aggregations and more or less dense schools. High-density schools (Fig. 4A) were mainly observed in the inshore area or in pelagic areas close to shallows. Large differences in the nature of aggregations were observed in different areas and in various vertical strata. During the night survey, fishes were scattered and no aggregations structures were observed (Fig. 4C).

\section{Acoustic biomass}

The acoustic biomass detected per sampling unit showed spatial and seasonal heterogeneities (Figs. 5 and 6). Regarding the vertical distribution, fishes were mainly observed in the intermediate layers (15-30 and $30-45 \mathrm{~m}$ ) in February (layer effect $F_{3,4016}=85.81$, $p<0.001)$; however, fishes were more abundant in the upper layers (3-15 and $15-30 \mathrm{~m}$ ) in July (layer effect $F_{3,5504}=352.5, p<0.001$ ). Furthermore the acoustic biomass was always low in the deepest layer ( $45-60 \mathrm{~m}$ ) with $84 \%$ and $61 \%$ of ESDUs without fish in February and July 2008, respectively (Fig. 6). However, when considering all of the layers, the percentage of units without fish detection became negligible, $<1 \%$ during both seasons. The highest acoustic biomass were observed in February in the southern and western basins (one-way ANOVA and post-hoc Tukey test, basin-effect $F_{3,1001}=45.66$, $p<0.001$ ) while in July only the South basin showed higher values than the others (basin effect $F_{3,1373}=6.739, p<0.001$ ).

The acoustic biomass detected in inshore areas were 3 to 8 times greater than in pelagic areas during both seasons $\left(F_{1,2611}=565.4\right.$, $p<0.001$; Table 2). The coefficients of variation (CV) of acoustic
A

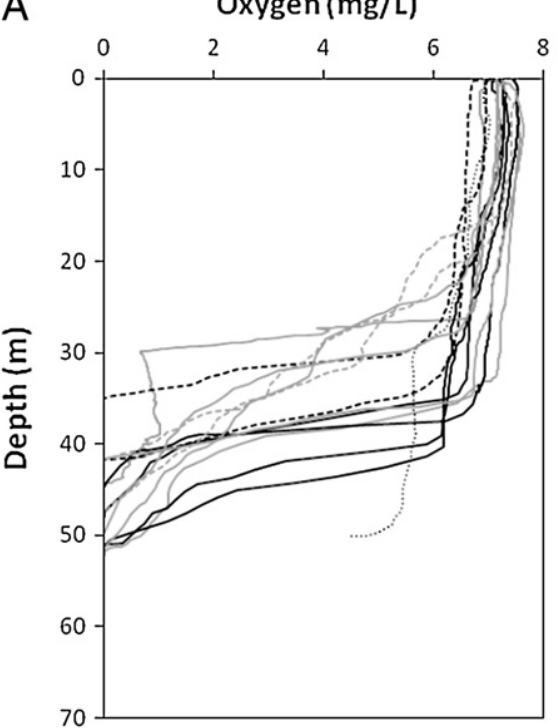

B

B Oxygen $(\mathrm{mg} / \mathrm{L})$

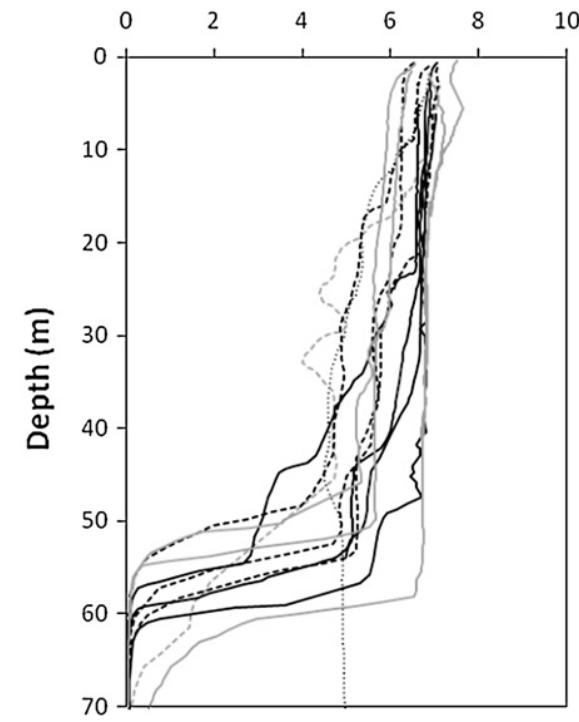

Fig. 3. Vertical profiles of dissolved oxygen in February (A) and July (B) 2008 in Lake Kivu. The continuous black lines represent vertical profiles of the North basin, the continuous grey lines of the East basin, the dashed black lines of the West basin, the dashed grey lines of the South basin and the dotted black line of Bukavu Bay. 

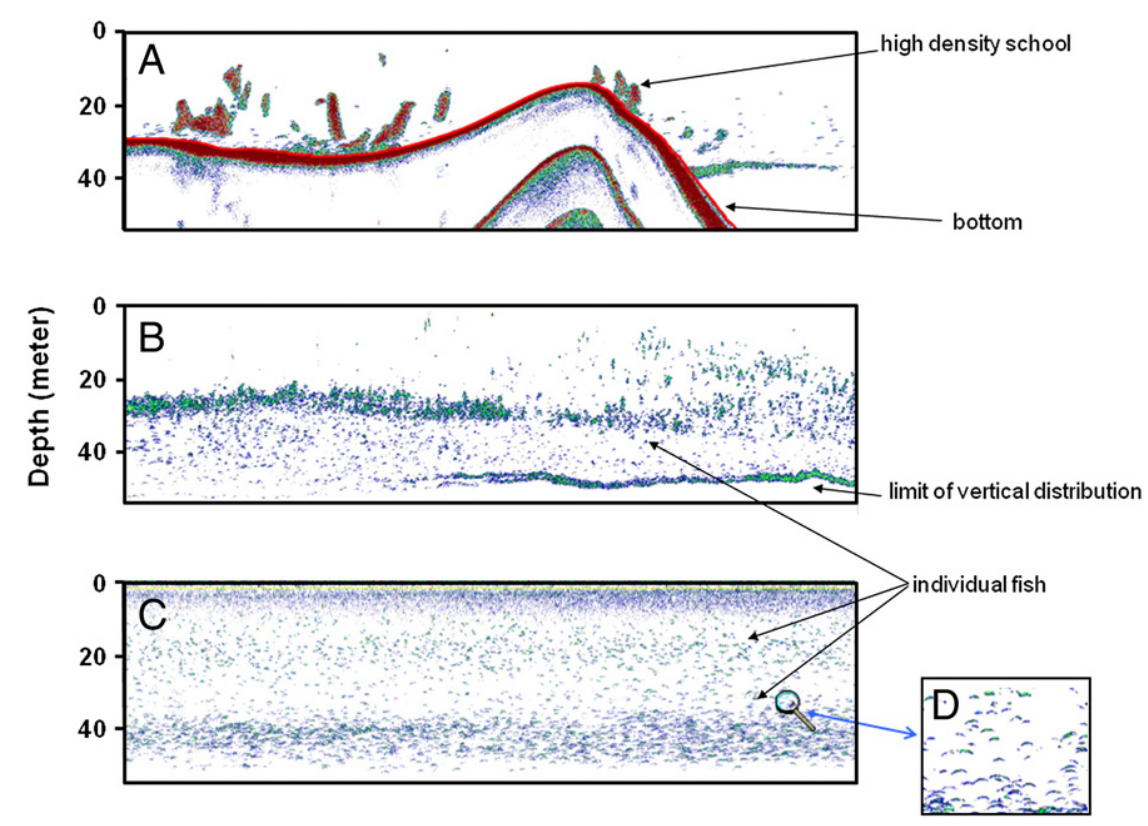

Fig. 4. Examples of echograms captured in the inshore area (A) and in the pelagic area (B) of Lake Kivu during daylight, in the pelagic area at night (C), and a zoom on individual fishes (D).

biomass by basin, which is a measure of spatial heterogeneity, ranged between 0.80 and 1.38 , depending on basin and survey (Table 2). The fish population showed a greater heterogeneous dispersion (higher CV) at both basin and whole-lake scales in February than in July 2008. Indeed, at whole-lake scale, the CV of acoustic biomass was higher in February than in July 2008 (modified Bennett's statistic = $29.452, p<0.001$ ), and at basin scale there was a significant difference between basin-specific CVs during the February survey (modified
Bennett's statistic $=4.218, p=0.040$ ) but not during the July survey (statistic $=1.292, p=0.256$ ).

\section{Size assessment}

Individual fish lengths, converted from TS data, ranged from 2 to $20 \mathrm{~cm}$ (Fig. 7). Some differences in fish length distributions were observed between basins or seasons (Kruskal-Wallis one-way analysis of variance, statistic $=1609.7, \mathrm{p}<0.001$; Fig. 7). Particularly, fishes
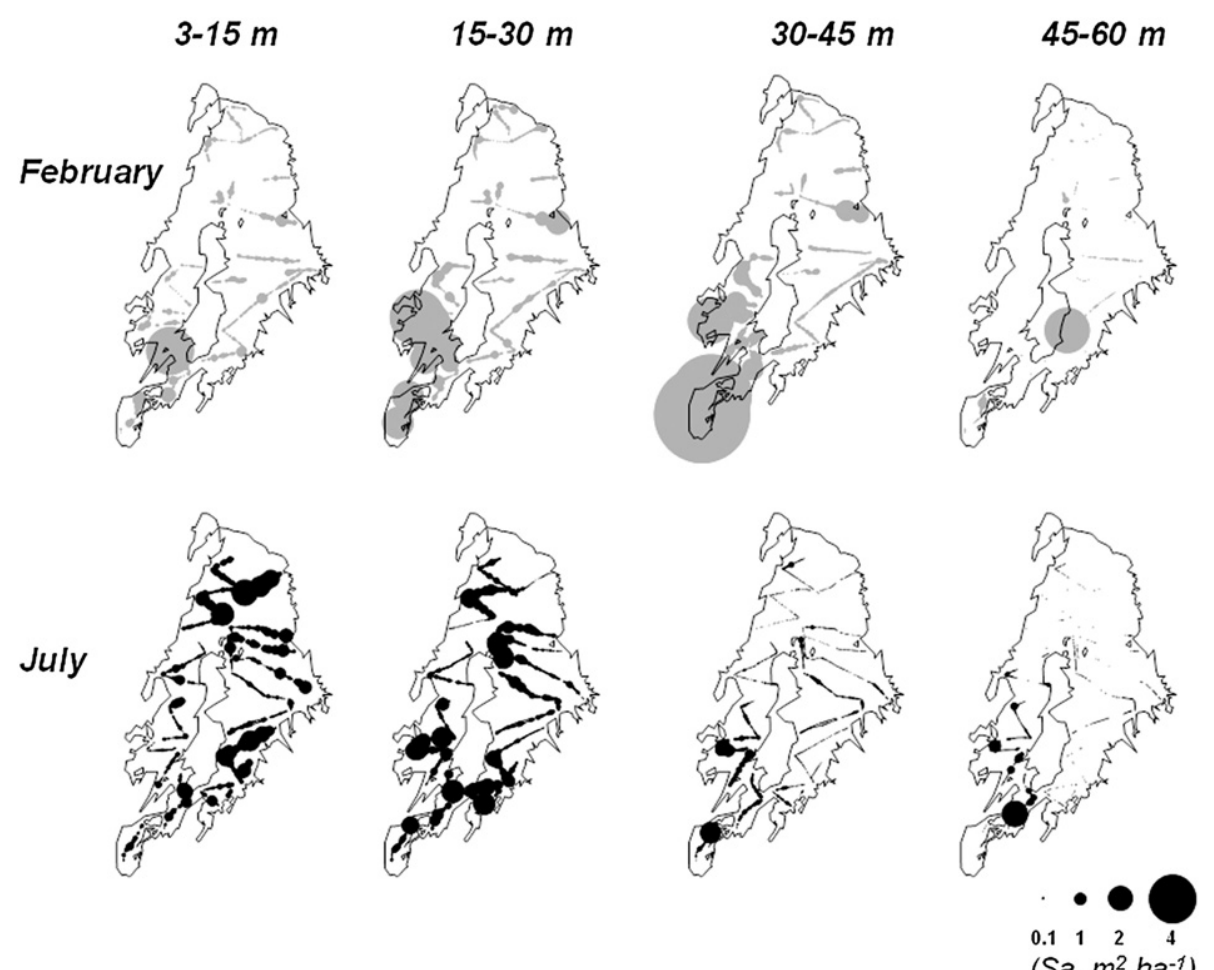

Fig. 5. Fish acoustic biomass detected by ESDU in the four vertical layers $(3-15,15-30,30-45,45-60 \mathrm{~m})$ in February (grey) and July (black) 2008 . The values are in $\mathrm{m}^{2}$ ha ${ }^{-1}$. 


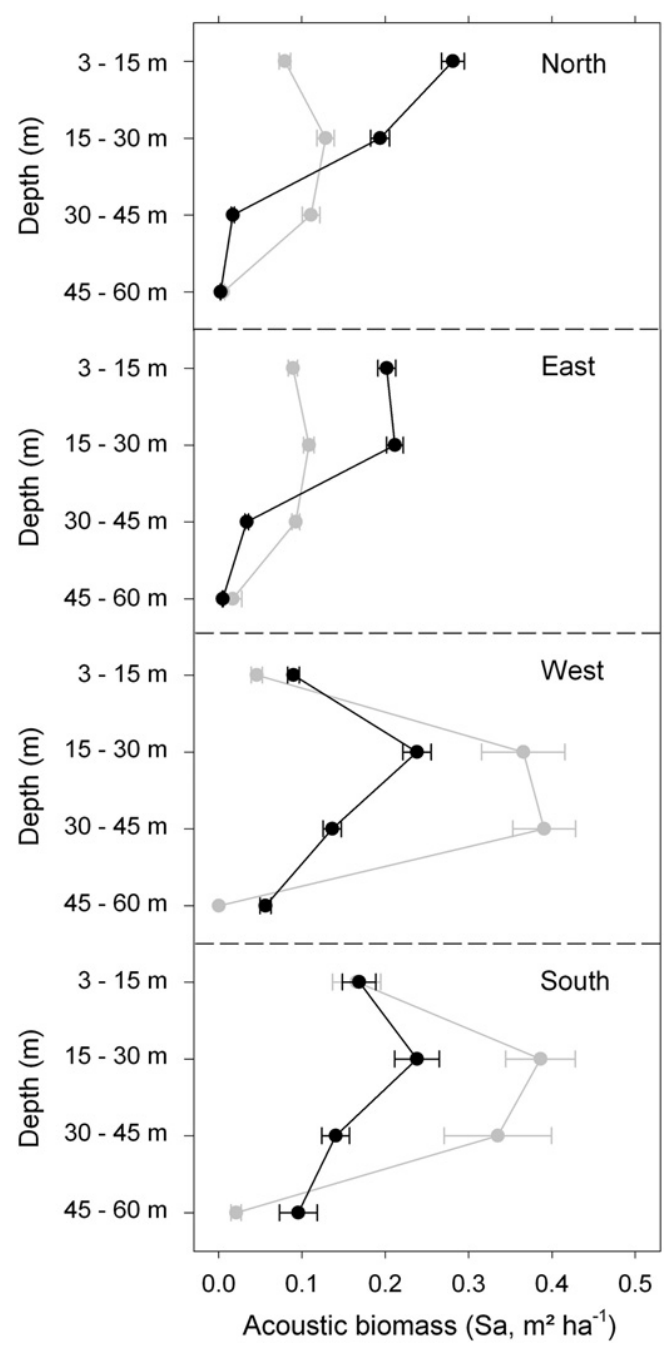

Fig. 6. Mean acoustic biomass ( \pm standard deviation) of the four vertical layers per basin in February (grey line) and July (black line) 2008.

longer than $10 \mathrm{~cm}$ were relatively more abundant in July than in February $(p<0.001)$ : they represented 25\% (acoustic biomassweighted mean) of total numbers of fishes in February for 34\% in July.

\section{Calculation of biomass}

The fish biomass per basin was determined using the mean acoustic biomass, $\mathrm{s}_{\mathrm{ai}}$, and TS frequency distribution of the considered basin. Results are given in Table 3. Due to their greater areas, the fish biomass was highest in the northern and eastern basins whatever the season. The western basin showed also a high biomass in February. The littoral areas counted for $12-13 \%$ of the total fish biomass while they represent only $2 \%$ of the total surface area. There was no difference of total fish biomass between both seasons, with a mean

Table 2

Mean and coefficient of variation (CV) of acoustic energy $\left(\mathrm{s}_{\mathrm{a}} \mathrm{m}^{2} \mathrm{ha}^{-1}\right)$ in the different lake areas and seasons.

\begin{tabular}{|c|c|c|c|c|c|c|}
\hline & North & East & West & South & Whole pelagic area & Inshore area \\
\hline \multicolumn{7}{|l|}{ February } \\
\hline $\begin{array}{l}\text { Mean sa } \\
(\mathrm{m} 2 . \mathrm{ha}-1)\end{array}$ & 0.324 & 0.306 & 0.802 & 0.908 & 0.497 & 2.336 \\
\hline $\mathrm{CV}$ & 1.13 & 0.90 & 1.18 & 1.38 & 1.49 & 1.74 \\
\hline \multicolumn{7}{|l|}{ July } \\
\hline $\begin{array}{l}\text { Mean sa } \\
(\mathrm{m} 2 . \mathrm{ha}-1)\end{array}$ & 0.495 & 0.452 & 0.520 & 0.642 & 0.497 & 2.989 \\
\hline $\mathrm{CV}$ & 0.85 & 0.80 & 0.92 & 0.84 & 0.86 & 1.04 \\
\hline
\end{tabular}

estimation of 5004 tons and 6036 tons, respectively in February and July (Table 3).

\section{Diel vertical migration}

In February, a survey was performed before and after dusk on a similar track (Fig. 8) to observe and quantify vertical distributions and changes in aggregation structures. On the echograms (Fig. 8), fish dispersion and migration at dusk to the $10-15 \mathrm{~m}$ layer were observed. Before dusk, the percentage of single echoes in each ESDU was near $22 \%$, whereas it was more than $40 \%$ during the night, showing a change from aggregations to scattered fish.

\section{Discussion}

Our surveys were performed during the daytime, similar to those conducted in the 1980s (Lamboeuf, 1991), with a sampling effort close to that recommended by Aglen (1989). Schooling of fish during daylight (Fréon and Misund, 1999) was observed, similarly to previous observations (Kaningini et al., 1999). Fish dispersion at dusk (Fréon et al., 1996) was also noted in the lake. This behaviour is often interpreted as an anti-predatory mechanism (Parrish et al., 2002; Pitcher and Parrish, 1993), but Lake Kivu has no predatory fish species in the pelagic zone, except large L. miodon for which predation upon its own fry in Lake Kivu has been reported (Kaningini, 1995). Acoustic surveys performed during the night, when distributions are more homogeneous, are typically more reliable than those performed during daylight (Simmonds and MacLennan, 2005). In our study, we assumed that daylight surveys were also reliable due to the relatively homogeneous distribution during daytime and because no fish were detected close to the surface. In Lake Kivu, the inshore area is limited due to its steep banks; therefore hydroacoustic sampling in the pelagic area allows reliable estimation of the vast majority of the stock (Brehmer et al., 2006). Nevertheless, although the inshore area of Lake Kivu represented $2 \%$ of the surface area, $12-13 \%$ of total biomass resided in this area. In these inshore zones, contrary to offshore zones where L. miodon was the dominant species (Kaningini et al., 1999), other fish species are present, especially L. tanganicanus (Masilya et al., 2011), leading to a possible overestimation of the L. miodon stock. Therefore additional samplings by complementary fishing methods should be conducted in future surveys to check for the abundances of $L$. tanganicanus in this area. Nevertheless, since the occurrence of $L$. tanganicanus is low in the pelagic zone (Masilya, 2011), their presence likely did not significantly biased our assessment of the $L$. miodon stock.

Notable differences in fish distributions in the pelagic zone were found. The biomass were higher in the western and southern basins in February, while only the South basin had higher biomass in July. However, fish biomass was more homogenous among basins during July than during February. Notably, the biomass of the southern and western basins significantly decreased between February and July, while values in the northern and eastern basins increased. Marshall (1991) noted a similar pattern, i.e. CPUE was higher in the South in February and in the North in July, and concluded that L. miodon undertook South to North migrations in Lake Kivu. However, due to a high variation in fishery activities (Kaningini et al., 1999) related to seasonal wind and waves conditions, the differences highlighted by Marshall (1991) might be questionable. High concentrations in the South basin in February were also described by Marshall (1991), who hypothesized that the morphology of this basin, with welldeveloped coastal zones were favorable to L. miodon reproduction. Past and present surveys show that fish were always limited to the upper $60 \mathrm{~m}$ of the water column (i.e. to the mixolimnion), but the deepest layer, 45-60 m, was devoid of fish in February. In July, this deepest layer supported low fish biomass, despite the whole mixolimnion was well oxygenated, and fishes were closer to the surface than in February. Fishes were not present in the surface layers, 

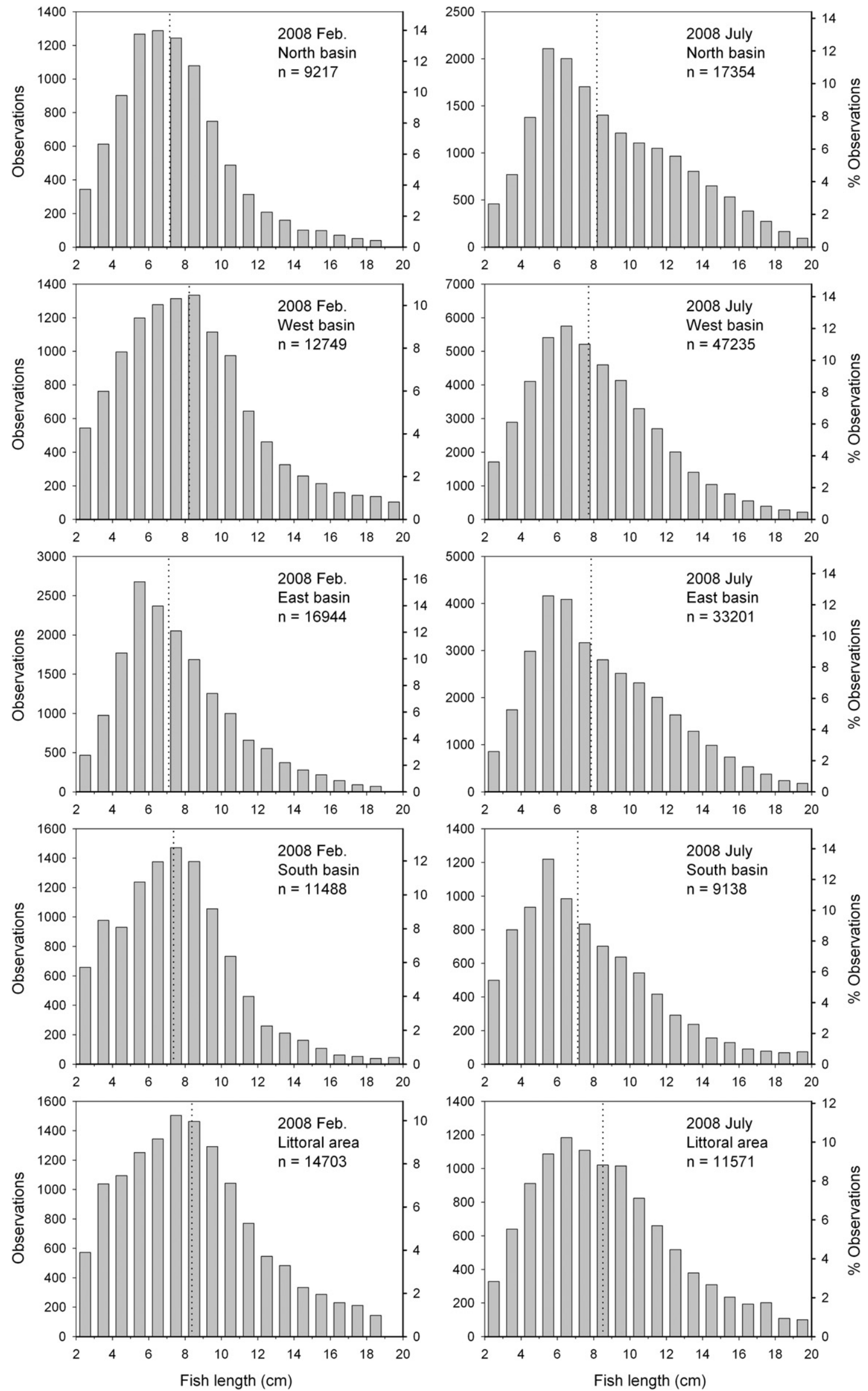
Table 3

Fish biomass in the different lake areas and seasons. 95\% confidence intervals (C.I.) were estimated by a bootstrap procedure.

\begin{tabular}{|c|c|c|c|c|c|c|c|}
\hline & North & East & West & South & Whole pelagic area & Inshore area & Whole lake \\
\hline \multicolumn{8}{|l|}{ February } \\
\hline $\begin{array}{l}\text { Biomass (T) } \\
(95 \% \text { C.I.) }\end{array}$ & $\begin{array}{l}1367 \\
(1210-1549)\end{array}$ & $\begin{array}{l}1295 \\
(1184-1426)\end{array}$ & $\begin{array}{l}1324 \\
(1100-1564)\end{array}$ & $\begin{array}{l}414 \\
(338-510)\end{array}$ & $\begin{array}{l}4399 \\
(3832-5049)\end{array}$ & $\begin{array}{l}605 \\
(450-800)\end{array}$ & $\begin{array}{l}5004 \\
(4283-5848)\end{array}$ \\
\hline \multicolumn{8}{|l|}{ July } \\
\hline $\begin{array}{l}\text { Biomass (T) } \\
95 \% \text { C.I. (T) }\end{array}$ & $\begin{array}{l}2183 \\
(2021-2352)\end{array}$ & $\begin{array}{l}1969 \\
(1832-2113)\end{array}$ & $\begin{array}{l}797 \\
(715-882)\end{array}$ & $\begin{array}{l}313 \\
(268-365)\end{array}$ & $\begin{array}{l}5263 \\
(4836-5712)\end{array}$ & $\begin{array}{l}773 \\
(615-945)\end{array}$ & $\begin{array}{l}6036 \\
(5451-6657)\end{array}$ \\
\hline
\end{tabular}

thus escape behaviours observed elsewhere (Guillard et al., 2010; Knudsen and Saegrov, 2002) should not be an issue. No spatial pattern of fish size distribution was observed in pelagic areas, which is consistent with the previous findings of Lamboeuf (1991). However, the proportion of small fish in the inshore areas was lower than in the pelagic zone whatever the season. Fish sizes were estimated using tracked fish, smoothing the variability due to behaviour and position. The number of detected targets was always considerable and the Sawada indexes were less than 0.1 as recommended by Rudstam et al. (2009). The size distributions were always unimodal (Fig. 7), which is representative of only one fish species, without marked cohorts. As L. miodon is by far the major pelagic fish species in Lake Kivu (Masilya, 2011), the transformation of TS to fish length was straightforward. In our study, the percentage of small targets representing juvenile fish (1-6 cm) (Kaningini, 1995), did not vary much in different basins and seasons and was approximately $30 \%$ of the total population based on the number of fish detected. Seasonal variation in the abundance of different size classes were noticed by Lamboeuf (1991) who used a single-beam sounder (EY200).

The two fish stock assessments were performed before the two main periods of $L$. miodon reproduction in Lake Kivu, i.e. March to May and August to October (Kaningini et al., 1999). The surveys led to an estimate of total fish stock of 5004 tons in February and of 6036 tons in July. Previous surveys (Kaningini et al., 1999) estimated the total fish biomass to be between 6000 and $10,000 \mathrm{t}$, while Lamboeuf (1991) estimated the biomass of L. miodon at 3445 to $5351 \mathrm{t}$ between April 1989 and June 1991. Also, the mean areal density we observed ( $23 \mathrm{~kg} \mathrm{ha}^{-1}$ ) was similar to that described by Lamboeuf (1991). Given the similarity of the approaches used and the comparable sampling design, we conclude that there has been no difference in the sardine stock between the end of the 1980s and 2008. It is worth noting that estimates made at the end of the 1980 s followed a period of stock decrease from 1981 to 1988, followed by a sharp increase in 1989 and 1990 (Lamboeuf, 1991; Marshall, 1991) and we cannot exclude that fish biomass varied during the two survey periods. While not significant, an approximately $20 \%$ increase in fish biomass was noted between February and July 2008. Actually, such a rise in fish biomass is within the range of natural stock fluctuations for this small pelagic fish (Marshall, 1993), and given the estimation errors, it should not be interpreted as a long-term trend. More frequent surveys, complementary with estimates of fisheries catches, should be performed to better understand the natural and human-caused fluctuations, as recently illustrated in Lake Kariba (Magadza, 2011).

A collapse of the L. miodon stock in Lake Kivu was predicted by Dumont (1986) due to a drop in the zooplankton size and abundance following the L. miodon introduction. Our hydroacoustic surveys demonstrate that the predicted collapse of $L$. miodon did not occur. The capacity of zooplankton communities to recover after a fish introduction has been reported in other lentic systems (see e.g. Harig and Bain, 1998; Knapp et al., 2001). Successful populations of alien species often rapidly increase in abundance, but then decline to what might be called an "equilibrium level" (Strayer and Malcom, 2007; Williamson, 1996). The L. miodon introduction in Lake Kivu might have followed this "boom-and-bust" dynamic, and we can reasonably assume that the zooplankton biomass decrease detected in the $1980 \mathrm{~s}$ was observed during the boom phase of L. miodon invasion. Unfortunately, data on the L. miodon dynamics in the years following the introduction are lacking. It is possible that the low zooplankton biomass reported by Dumont (1986) was a short-term effect, and that after some time both zooplankton and fish communities reached a more stable system state in Lake Kivu. This is in accordance to recent observations on the zooplankton community in Lake Kivu (Darchambeau et al., in press; Isumbisho et al., 2006). Re-analysis of past and recent zooplankton records indicates that zooplankton biomass before the sardine introduction may have been as high as $3 \mathrm{~g} \mathrm{Cm}^{-2}$, whereas the biomass in 2003-2004 was $\sim 1 \mathrm{~g} \mathrm{Cm}^{-2}$, suggesting a strong decline from the past situation without a planktivore fish. However, the present zooplankton biomass in lake Kivu is comparable to that of other great lakes of the East African rift (Darchambeau et al., in press), and may represent a new equilibrium biomass for zooplankton in the presence of planktivorous fish.

As already outlined (Lamboeuf, 1991; Marshall, 1993; Roest, 1999), L. miodon densities in Lake Kivu are low in comparison with lakes or reservoirs where the species is naturally present (Lake Tanganyika) or was introduced (Lakes Kariba and Cahora Bassa). The mean L. miodon biomass in 2008 in Lake Kivu $\left(23 \mathrm{~kg} \mathrm{ha}^{-1}\right)$ is notably lower than the sardine biomass in Lake Tanganyika, where estimates range from $60 \mathrm{~kg} \mathrm{ha}^{-1}$ (Szczucka, 1998) to $300 \mathrm{~kg} \mathrm{ha}^{-1}$ (Moreau and Nyakageni, 1988). Worth noticing, however, is that these figures are based on the fishery yield of the two sardine species inhabiting Lake Tanganyika, Stolothrissa tanganicae and L. miodon. The reasons for the low L. miodon density in Lake Kivu are not known (Descy et al., 2012). Indeed, total phytoplankton and zooplankton productions are comparable across East African Great lakes (Darchambeau et al., 2012; Sarmento et al., 2012). Among the possible explanations, large fluctuations in clupeid stocks have been reported from other systems, in which variations of recruitment and larval survival may play a significant role (Kimirei and Mgaya, 2007; Mölsä et al., 2002). In addition local people around Lake Kivu often use illegal fishing techniques for catching young fish in the inshore aeras (Kaningini et al., 1999) where the growth of L. miodon larvae and juveniles takes place (Masilya, 2011). This potentially harmful practice, coupled with the incidence of predation by L. miodon adults and other fish species in the inshore areas (De Iongh et al., 1983; Masilya, 2011), might significantly reduce larvae survival. Moreover, strong competition for resources may occur in these inshore zones (Masilya, 2011) which harbour almost all the fish diversity in Lake Kivu, with several haplochromine species (Snoeks et al., 1997).

\section{Conclusion}

Given that the pelagic area of Lake Kivu is dominated by L. miodon (Kaningini et al., 1999; Masilya, 2011) the two hydroacoustic surveys

Fig. 7. Fish length distributions, converted from TS data, from in $1 \mathrm{~cm}$ classes by season and for the four basins plus the littoral area. The dotted lines represent the median values. 

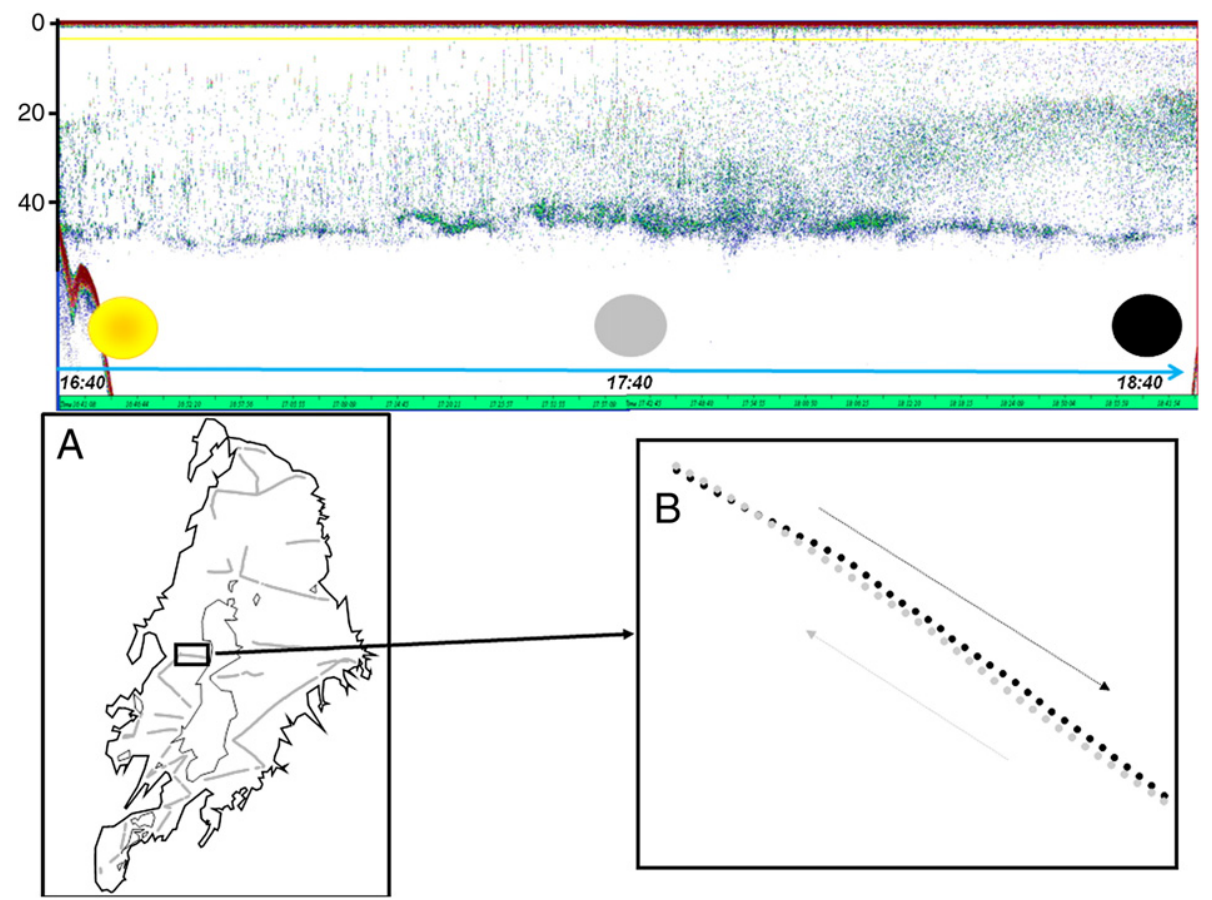

Fig. 8. Echogram recorded continuously from 16:40 to 19:00 GMT (dusk from 17:30 to 17:50 GMT), showing the detected fish (see Fig. 4) with the area (A) where the survey was performed indicated by a black rectangle, and a zoom (B) with the way forward, in grey, and the way back, in black.

performed in 2008 in Lake Kivu provided estimates of L. miodon biomass of 5004 tons (February) and 6036 tons (July). These results are similar to those reported at the end of the 1980s. Thus, contrary to predictions based on changes in the zooplankton assemblage, the stock of $L$. miodon did not collapse, but remained stable, despite a likely increase in the fishing effort. Based on the data presented here, the pelagic fishery on L. miodon in Lake Kivu appears sustainable. However, further hydroacoustic studies should examine the variations of the fish stocks in the lake. These surveys should be complemented by an assessment of the fishing effort over the whole lake in order to define management strategies for ensuring sustainability in the future. This becomes all the more relevant in the context of the methane exploitation (Nayar, 2009), which may in the long term affect both the environmental conditions and the resources available to the pelagic fish in Lake Kivu (Descy et al., 2012)

\section{Acknowledgments}

We are grateful to Boniface Kaningini and Pascal Isumbisho Mwapu (Institut Supérieur Pédagogique, Bukavu, République Démocratique du Congo), to Laetitia Nyinawamwiza (National University of Rwanda, Butare, Rwanda) and their respective teams for their logistic support during the trips, and to Bruno Leporcq for his help during field sampling. This work was funded by the Commission Universitaire pour le Développement (CUD) under the ECOSYKI (Etude du fonctionnement de l'écosystème du lac Kivu en vue de son exploitation durable) project and by the Fonds National de la Recherche Scientifique (FNRS) under the CAKI (Cycle du carbone et des nutriments au Lac Kivu, contract $n^{\circ}$ 2.4.598.07) project. Likewise, this study contributes to the Belgian Federal Science Policy Office EAGLES (East African Great Lake Ecosystem Sensitivity to changes, SD/AR/02A) project. FD was a posdoctoral researcher at the FNRS. In addition, we thank two anonymous referees for their helpful comments.

\section{References}

Aglen, A., 1989. Empirical results on precision-effort relationships for acoustic surveys. ICES CM B/30.
Balk, H., Lindem, T., 2006. Sonar 4, Sonar 5, Sonar 6 - post-processing systems. Operator Manual. University of Oslo, Norway.

Beadle, L.C., 1981. The inland waters of tropical Africa, an introduction to tropical limnology. Longman, London.

Brehmer, P., Guillard, J., Guennégan, Y., Bigot, J.L., Liorzou, B., 2006. Evidence of a variable "unsampled" biomass along the shallow water $(<20 \mathrm{~m})$ coastline in small pelagic fish stock assessment method. ICES J. Mar. Sci. 63, 444-451.

Collart, A., 1960. L'introduction du Stolothrissa tanganicae (Ndagala) au lac Kivu. Bull. Agric. Congo Belge 51 (4), 975-985.

Coulter, G.W., 1991. Lake Tanganyika and its Life. Oxford University Press, London.

Darchambeau, F., Isumbisho, M., Descy, J.-P., 2012. Zooplankton of Lake Kivu. In: Descy, J.-P., Darchambeau, F., Schmid, M. (Eds.), Lake Kivu - Limnology and biogeochemistry of a tropical great lake: Aquatic Ecology Series, vol. 5, Springer, pp. 107-126.

De Iongh, H.H., Spliethoff, P.C., Frank, V.G., 1983. Feeding habits of the clupeid Limnothrissa miodon (Boulenger), in Lake Kivu. Hydrobiologia 102, 113-122.

Degens, E.T., Von Herzen, R.P., Wong, H.-K., Deuser, W.G., Jannasch, H.W., 1973. Lake Kivu: structure, chemistry and biology of an East African Rift Lake. Geol. Rundsch. 62, 245-277.

Descy, J.-P., Darchambeau, F., Schmid, M., 2012. Lake Kivu - limnology and biogeochemistry of a tropical great lake. Aquatic Ecology Series, vol. 5. Springer.

Dumont, H.J., 1986. The Tanganyika Sardine in Lake Kivu: another ecodisaster for Africa? Environ. Conserv. 13 (2), 143-148.

Dunlop, E.S., Milne, S.W., Ridgway, M.S., 2010. Temporal trends in the numbers and characteristics of Lake Huron fish schools between 2000 and 2004. J. Great Lakes Res. 36 (1), 74-85.

FAO, 1992. Développement de la pêche au lac Kivu, Rwanda. Conclusions et recommandations du projet. FAO FI:DP/RWA/87/012.

Foote, K.G., Knudsen, H.P., Vestnes, G., MacLennan, D.N., Simmonds, E.J., 1987. Calibration of acoustic instruments for fish-density estimation: a practical guide. ICES Cooper. Res. Rep.

Fréon, P., Misund, O.A., 1999. Dynamics of pelagic fish distribution and behaviour: effects on fisheries and stock assessment. Fishing new books. Blackwell Science, Oxford, U.K

Fréon, P., Gerlotto, F., Soria, M., 1996. Diel variability of school structure with special reference to transition. ICES J. Mar. Sci. 53, 459-464.

Godlewska, M., Colon, M., Jozwika, A., Guillard, J., 2011. How pulse lengths impact fish stock estimations during hydroacoustic measurements at $70 \mathrm{kHz}$. Aquat. Living Resour. 24, 71-78.

Gozlan, R.E., 2008. Introduction of non-native freshwater fish: is it all bad? Fish Fish. 9 $106-115$.

Guillard, J., Marchal, E., 2001. L'hydroacoustique, méthode d'étude de la distribution spatiale et de l'abondance des peuplements pisciaires lacustres. In: Gerdeaux, D. (Ed.), La gestion piscicole des grands plans d'eaux, INRA Paris, pp. 215-239.

Guillard, J., Vergés, C., 2007. The repeatability of fish biomass and size distribution estimates obtained by hydroacoustic surveys using various survey designs and statistical analyses. Int. Rev. Hydrobiol. 92 (6), 605-617.

Guillard, J., Perga, M.-E., Colon, M., Angeli, N., 2006. Hydroacoustic assessment of young-of-year perch, Perca fluviatilis, population dynamics in an oligotrophic lake (Lake Annecy, France). Fish. Manag. Ecol. 13, 319-327. 
Guillard, J., Balay, P., Colon, M., Brehmer, P., 2010. Survey boat effect on YOY fish schools in a pre-alpine lake: evidence from multibeam sonar and split-beam echosounder data. Ecol. Freshw. Fish 19, 373-380.

Haberyan, K.A., Hecky, R.E., 1987. The late Pleistocene and Holocene stratigraphy and paleolimnology of Lakes Kivu and Tanganyika. Palaeogeogr. Palaeoclimatol. Palaeoecol. 61, 169-197.

Harig, A.L., Bain, M.B., 1998. Defining and restoring biological integrity in wilderness lakes. Ecol. Appl. 8, 71-87.

Isumbisho, M., Kaningini, B., Descy, J.-P., Baras, E., 2004. Seasonal and diel variations in diet of the young stages of the fish Limnothrissa miodon in Lake Kivu, Eastern Africa. J. Trop. Ecol. 20, 73-83.

Isumbisho, M., Sarmento, H., Kaningini, B., Micha, J.-C., Descy, J.-P., 2006. Zooplankton of Lake Kivu, half a century after the Tanganyika sardine introduction. J. Plankton Res. 28 (10), 1-19.

Johnson, T.B., Hoff, M.H., Trebitz, A.S., Bronte, C.R., Corry, T.D., Kitchell, J.F., Lozano, S.J., Mason, D.M., Scharold, J.V., Schram, S.T., Schreiner, D.R., 2004. Spatial patterns in assemblage structures of pelagic forage fish and zooplankton in Western Lake Superior. J. Great Lakes Res. 30 (1), 395-406.

Kaningini B., 1995. Etude de la croissance, de la reproduction et de l'exploitation de Limnothrissa miodon au lac Kivu, bassin de Bukavu (Zaïre). Thèse de Doctorat en Sciences, Biologie, F.U.N.D.P., Facultés des Sciences, Namur, Belgium.

Kaningini, B., Micha, J.-C., Vandenhaute, J., Platteau, J.-P., Watongoka, H., Mélard, C., Wilondja, M.K., Isumbisho, M., 1999. Pêche du Sambaza au filet maillant dans le lac Kivu. Presses Universitaires de Namur, Namur, Belgium.

Kaningini, M., Isumbisho, M., Ndayike, N., Micha, J.-C., 2003. L'étude du zooplancton du lac Kivu : composition, variations saisonnières d'abondance et distribution. Bull. Séanc. Acad. R. Sci. Outre - Mer 49 (2), 145-160.

Kimirei, I.A., Mgaya, Y.D., 2007. Influence of environmental factors on seasonal changes in clupeid catches in the Kigoma area of Lake Tanganyika. Afr. J. Aquat. Sci. 32, 291-298.

Knapp, R.A., Matthews, K.R., Sarnelle, O., 2001. Resistance and resilience of alpine lake fauna to fish introductions. Ecol. Monogr. 71, 401-421.

Knudsen, F.R., Sægrov, H., 2002. Benefits from horizontal beaming during acoustic survey: application to three Norwegian lakes. Fish. Res. 56, 205-211.

Kurkilahti, M., Appelberg, M., Hesthagen, T., Rask, M., 2002. Effect of fish shape on gillnet selectivity: a study with Fulton's condition factor. Fish. Res. 54, 153-170.

Kwetuenda, M., Nakao, K., Kagogozo, B., 1989. Climatic conditions in the hydrological basin of Lake Kivu during 12 years. In: Kawanabe, H., Nagoshi, M. (Eds.), Ecological and limnological study on Lake Tanganyika and its adjacent regions, Kyoto, Japan, pp. $55-56$.

Lamboeuf, M., 1989. Estimation de l'abondance du stock d'Isambaza (Limnothrissa miodon), résultats de la prospection acoustique de septembre 1989. RWA/87/ 012/DOC/TR/20

Lamboeuf, M., 1991. Abondance et répartition du Limnothrissa miodon du lac Kivu, résultat des prospections acoustiques d'avril 1989 à juin 1991. RWA/87/012/DOC/TR/46.

Leprieur, F., Brosse, S., Garcia-Berthou, E., Oberdorff, T., Olden, J.D., Townsend, C.R., 2009. Scientific uncertainty and the assessment of risks posed by non-native freshwater fishes. Fish Fish. 10, 88-97.

MacLennan, D., Fernandes, P.G., Dalen, J., 2002. A consistent approach to definitions and symbols in fisheries acoustics. ICES J. Mar. Sci. 59, 365-369.

Magadza, C.H.D., 2011. Indications of the effect of climate change on the pelagic fishery of Lake Kariba, Zambia-Zimbabwe. Lakes Reservoirs Res. Manage. 16, 15-22.

Marshall, B.E., 1991. Seasonal and annual variations in the abundance of the clupeid Limnothrissa miodon in Lake Kivu. J. Fish Biol. 39, 641-648.

Marshall, B.E., 1993. Biology of the African clupeid Limnothrissa miodon with reference to its small size in artificial lakes. Rev. Fish Biol. Fish. 3, 17-38.

Masilya P., 2011. Ecologie alimentaire de Limnothrissa miodon au Lac Kivu (Afrique de l'Est). PhD thesis, University of Namur, Belgium.

Masilya, M.P., Darchambeau, F., Isumbisho, M., Descy, J.-P., 2011. Diet overlap between the newly introduced Lamprichthys tanganicanus and the Tanganyika sardine in Lake Kivu, Eastern Africa. Hydrobiologia 675, 75-86.

Mölsä, H., Sarvala, J., Badende, S., Chitamwebwa, D., Kanyaru, R., MuliMbwa, N., Mwape, L., 2002. Ecosystem monitoring in the development of sustainable fisheries in Lake Tanganyika. Aquat. Ecosyst. Health Manage. 5, 267-281.

Moreau, J., Nyakageni, B., 1988. Les relations trophiques dans la zone pélagique du lac Tanganyika (secteur Burundi). Essai d'évaluation. Rev. Hydrobiol. Trop. 21, 357-364.
Moreau, J., Arrignon, J.Jubb, R.A., 1988. Les introductions d'espèces étrangères dans les eaux continentales africaines. Intérêts et limites. In: Lévêsque, C. Bruton, M.N Sentongo, G.W. (Eds.), Biologie et écologie des poissons d'eau douce africains. Editions de l'ORSTOM, France, pp. 221-242.

Muderhwa, N., Matabaro, L., 2010. The introduction of the endemic fish species, Lamprichthys tanganicanus (Poeciliidae), from Lake Tanganyika into Lake Kivu: Possible causes and effects. Aquat. Ecosyst. Health Manage. 13 (2), 203-213.

Nayar, A., 2009. A lakeful of trouble. Nature 460, 321-323.

Ogutu-Ohwayo, R., Hecky, R., Cohen, A.S., Kaufman, N.L., 1997. Human impacts on the African Great Lakes. Environ. Biol. Fish. 50, 117-131.

Parrish, J., Viscido, S., Grünbaum, D., 2002. Self-Organized Fish Schools: An Examination of Emergent Properties. Biol. Bull. 202, 296-305.

Pasche, N., Alunga, G., Mills, K., Muvundja, F., Ryves, D.B., Schurter, M., Wehrli, B. Schmid, M., 2010. Abrupt onset of carbonate deposition in Lake Kivu during the 1960s: response to recent environmental changes. J. Paleolimnol. 44 931-946.

Pitcher, T.J., Parrish, J.K., 1993. Function of shoaling behavior in teleosts. In: Pitcher, T.J. (Ed.), Behaviour of Teleost Fishes. Chapman and Hall, London, U.K., pp. 363-439.

Prchalováa, M., Kubecka, J., Ríha, M., Mrkvicka, T., Vasek, M., Juza, T., Kratochvíl, M. Peterka, J., Drastík, V., Krízekd, J., 2009. Size selectivity of standardized multimesh gillnets in sampling coarse European species. Fish. Res. 96, 51-57.

Roest, F.C., 1999. Introduction of a pelagic fish into a large natural Lake : Lake Kivu, Central Africa. In: Van Densen, W.L.T., Morris, M.J. (Eds.), Fish and Fisheries of Lakes and Reservoirs in Southeast Asia and Africa. Westbury Academic and Scientific Pub, Otley (United Kingdom), pp. 327-338.

Rudstam, L.G., Parker-Stetter, S.L., Sullivan, P.J., Warner, D.M., 2009. Towards a standard operating procedure for fishery acoustic surveys in the Laurentian Great Lakes, North America. ICES J. Mar. Sci. 66, 1391-1397.

Sala, O.E., Chapin III, F.S., Armesto, J.J., Berlow, E., Bloomfield, J., Dirzo, R., HuberSanwald, E., Huenneke, L.F., Jackson, R.B., Kinzig, A., Leemans, R., Lodge, D.M Mooney, H.A., Oesterheld, M., LeRoy Poff, N., Sykes, M.T., Walker, B.H., Walker M., Wall, D.H., 2000. Global Biodiversity Scenarios for the Year 2100. Science 287, 1770-1774.

Sarmento, H., Isumbisho, M., Descy, J.-P., 2006. Phytoplankton ecology of Lake Kivu (Eastern Africa). J. Plankton Res. 28 (9), 815-829.

Sarmento, H., Darchambeau, F., Descy, J.-P., 2012. Phytoplankton of Lake Kivu. In: Descy, J.-P., Darchambeau, F., Schmid, M. (Eds.), Lake Kivu - Limnology and biogeochemistry of a tropical great lake, Aquatic Ecology Series, vol. 5, Springer, pp. 67-84.

Shafer, N.J., Sullivan, J.A., 1986. A simulation study of a test for the equality of the coefficients of variation. Commun. Stat. - Simul. Comput. 15, 681-695.

Simmonds, E.J., MacLennan, D.N., 2005. Fisheries Acoustics: Theory and Practice. Blackwell Science Ltd., Oxford.

Smith, S., 1990. Use of statistical models for the estimation of abundance from groundfish survey data. Can. J. Fish. Aquat. Sci. 47, 894-903.

Snoeks, J., De Vos, L., Thys Van den Audenaerde, D., 1997. The ichthyogeography of Lake Kivu. S. Afr. J. Sci. 93, 579-584.

Snoeks, J., Kaningini, B., Nyinawamwiza, L., Guillard, J., 2012. Fishes: diversity and fisheries. In: Descy, J.-P., Darchambeau, F., Schmid, M. (Eds.), Lake Kivu - Limnology and biogeochemistry of a tropical great lake, Aquatic Ecology Series, vol. 5, Springer, pp 127-152.

Spliethoff, P.C., De Iongh, H.H., Frank, V., 1983. Success of the introduction of the freshwater Clupeid Limnothrissa miodon (Boulenger) in Lake Kivu. Fish. Manag. 14, $17-31$.

Strayer, D.L., Malcom, H.M., 2007. Effects of zebra mussels (Dreissena polymorpha) on native bivalves: the beginning of the end or the end of beginning? J. N. Am Benthol. Soc. 26, 111-122.

Szczucka, J., 1998. Acoustical estimation of fish abundance and their spatial distributions in Lake Tanganyika. FAO/FINNIDA Research for the Management of the Fisheries of Lake Tanganyika. GCP/RAF/271/FIN-TD/84

Vitousek, P.M., Mooney, H.A., Lubchenco, J., Melillo, J.M., 1997. Human Domination of Earth's Ecosystems. Science 277, 494-499.

Vitule, J.R.S., Freire, C.A., Simberloff, D., 2009. Introduction of non-native freshwater fish can certainly be bad. Fish Fish. 10, 98-108.

Williamson, M., 1996. Biological Invasions. Chapman and Hall, London. 